\title{
HUBUNGAN KARAKTERISTIK PELAKU UTAMA PERIKANAN DENGAN KEBUTUHAN MATERI PENYULUHAN PERIKANAN (STUDI KASUS DI KABUPATEN PURBALINGGA PROVINSI JAWA TENGAH)
}

\author{
oleh \\ Abdul Hanan, Walson H. Sinaga, Nayu Nurmalia \\ Dosen Jurusan Penyuluhan Perikanan Sekolah Tinggi Perikanan
}

\begin{abstract}
Abstrak
Beberapa faktor internal pembudidaya ikan di Kabupaten Purbalingga seperti tingkat kekosmpolitan dan tingkat keinovatifan merupakan karakteristik yang sangat berkorelasi dengan tingkat kebutuhan para pembudidaya terhadap kebutuhan informasi penyuluhan perikanan. Karateristik tersebut yang sangat membantu kreatifitas penyuluh perikanan dalam menyiapkan materi penyuluhan perikanan.

Totok Mardikantoro (1991) membedakan ada tiga macam materi penyuluhan berdasarkan sifatnya yaitu: 1) Yang berisikan pemecahan masalah yang sedang dan akan dihadapi, materi yang berisikan pemecahan masalah merupakan kebutuhan utama yang diperlukan oleh pelaku utama perikanan sebagai sasaran penyuluhan. Oleh karena itu, dalam setiap kegiatan penyuluhan, materi ini harus diutamakan terlebih dahulu sebelum materi-materi yang lainnya; 2) Yang berisikan petunjuk atau rekomendasi, yang harus dilaksanakan materi penyuluhan yang berupa petunjuk/rekomendasi yang harus dilaksanakan, sering kali sangat diharapkan oleh masyarakat sasaran, meskipun kurang memperoleh prioritas dibandingkan materi yang berisi pemecahan masalah. Karena itu materi ini hanya dibatasi pada petunjuk/rekomendasi yang harus segera dilaksanakan; 3) Materi yang bersifat instrumental.

Materi penyuluhan seperti ini tidak harus dikonsumsi dalam waktu cepat, tetapi merupakan materi yang perlu diperhatikan dan mempunyai manfaat jangka panjang.

Apapun materi penyuluhan yang disampaikan oleh seorang penyuluh, pertama-tama harus diingat bahwa materi tersebut harus selalu mengacu kepada kebutuhan yang telah dirasakan oleh masyarakat sasarannya. Keragaman sasaran yang dihadapi menjadi kendala bagi penyuluh dalam menentukan materi penyuluhan.
\end{abstract}

Kata Kunci: karakteristik internal, kebutuhan, materi penyuluhan

\section{PENDAHULUAN}

\section{Latar Belakang}

Peningkatan kualitas sumberdaya manusia perikanan dapat ditumbuhkan dengan usaha peningkatan pengetahuan dan keterampilan serta pemberian motivasi melalui kegiatan penyuluhan perikanan. Penyuluhan perikanan adalah pendidikan non formal yang ditujukan kepada masyarakat khususnya nelayan, pembudidaya dan pengolah hasil perikanan beserta keluarganya untuk meningkatkan pengetahuan, keterampilan, sikap dan motivasi dalam bidang perikanan (Anonimous, 2003). Kegiatan penyuluhan merupakan upaya untuk mengatasi kesenjangan pelaku utama terkait usaha 
perikanan. Kebutuhan penyuluhan adalah kesenjangan kompetensi yang dapat diatasi dengan kegiatan penyuluhan. Kesenjangan kompetensi pada pelaku utama perikanan adalah pada aspek perilaku yaitu masalah kognitif (kurang pengetahuan), masalah psikomotorik (rendahnya keterampilan) dan masalah afektif (sikap, dan nilai-nilai yang kurang mendukung optimalisasi kinerja).

Berkaitan dengan kompetensi tertentu, pelaku utama perikanan dapat berada empat kategori, yaitu: (1) belum menyadari bahwa dirinya belum kompeten, (2) menyadari bahwa dirinya belum kompeten, (3) menyadari dirinya kompeten, (4) belum menyadari bahwa dirinya sudah kompeten. Berkaitan dengan hal tersebut kebutuhan kegiatan penyuluhan ada pada kategori pertama dan paling banyak pada katagori kedua (Donaldson \& Scannel) pada Alimin (2004).

Menurut Anonimous (2006) tentang Sistem Penyuluhan Pertanian, Perikanan, dan Kehutanan, bahwa materi penyuluhan dibuat berdasarkan kebutuhan dan kepentingan pelaku usaha dengan memperhatikan kemanfaatan dan kelestarian sumber daya pertanian, perikanan dan kehutanan. Dengan demikian materi penyuluhan tersebut berisi unsur pengembangan sumberdaya manusia dan peningkatan modal sosial serta unsur ilmu pengetahuan, teknologi, ekonomi, manajemen, hukum dan pelestarian lingkungan. Materi penyuluhan pada hakekatnya merupakan segala pesan yang ingin dikomunikasikan oleh seorang penyuluh kepada masyarakat sasaranya

Pada pelaku utama perikanan materi penyuluhan meliputi: 1) Proses Produksi. Yang menurut Nuraeni (2002), proses produksi merupakan suatu cara, metode atau tehnik untuk menciptakan atau menambahkan kegunaan suatu barang atau jasa dengan menggunakan sumber-sumber, 2) Pasca Produksi, kegiatan pasca produksi hal yang perlu dilakukan selanjutnya adalah melakukan pengemasan sehingga menarik minat konsumen. Kemasan yang bagus adalah dengan memakai plastik dan dengan hampa udara sehingga dapat bertahan lama (Rahardi, 2008), 3) Pemasaran, adalah sejumlah kegiatan bisnis yang ditujukan untuk memberi kepuasan dari barang atau jasa yang dipertukarkan kepada konsumen atau pemakai (Laksana, 2008). Menurut Rahardi (2008), pemasaran merupakan aspek yang sangat mendasar dalam mencapai keuntungan. Jika produksi besar, tetapi tidak memiliki sasaran pasar maka hasil produksi tidak akan bisa terjual.

Proses belajar dalam kegiatan penyuluhan merupakan proses komunikasi. Efektifitas komunikasi terkait dengan (Lionberger \& Gwin, 1982) : (1) variabel personal antara lain, umur dan pendidikan, (2) variabel situasional, antara lain, ukuran usaha, kelompok sosial, dan penawaran tenaga kerja; (3) variabel pendahulu, antara lain akses informasi, saprokan, dan pendidikan penyuluh; (4) variabel tingkah laku, yaitu perubahan tingkah laku dan tujuan bertingkah laku.

Ciri-ciri pelaku utama perikanan berkaitan erat dengan keputusan pengelolaan usaha. Ciri-ciri dimaksud meliputi: (Roger \& Soemaker,1987):

1) karakteristik sosio ekonomik antara lain: pendidikan, mobilitas sosial, ukuran usaha, orientasi usaha dan sikap terhadap inovasi; (2) varibel personalitas antara lain: motivasi meningkatnya taraf hidup serta aspirasi terhadap pendidikan dan pekerjaan;

2) perilaku komunikasi antara lain: partisipasi sosial, komunikasi interpersonal dengan anggota dan bukan anggota sistem sosial, kontak dengan agen pembaharu. 
KERANGKA PIKIR DAN HIPOTESIS

Pelaku utama perikanan mengikuti
kegiatan penyuluhan $\quad$ lazimnya
mepertimbangkan faktor-faktor pribadi dan keluarganya, usahanya, serta faktor eksternalnya. Berdasarkan hal tersebut disusun suatu kerangka pikir seperti pada Gambar 1.

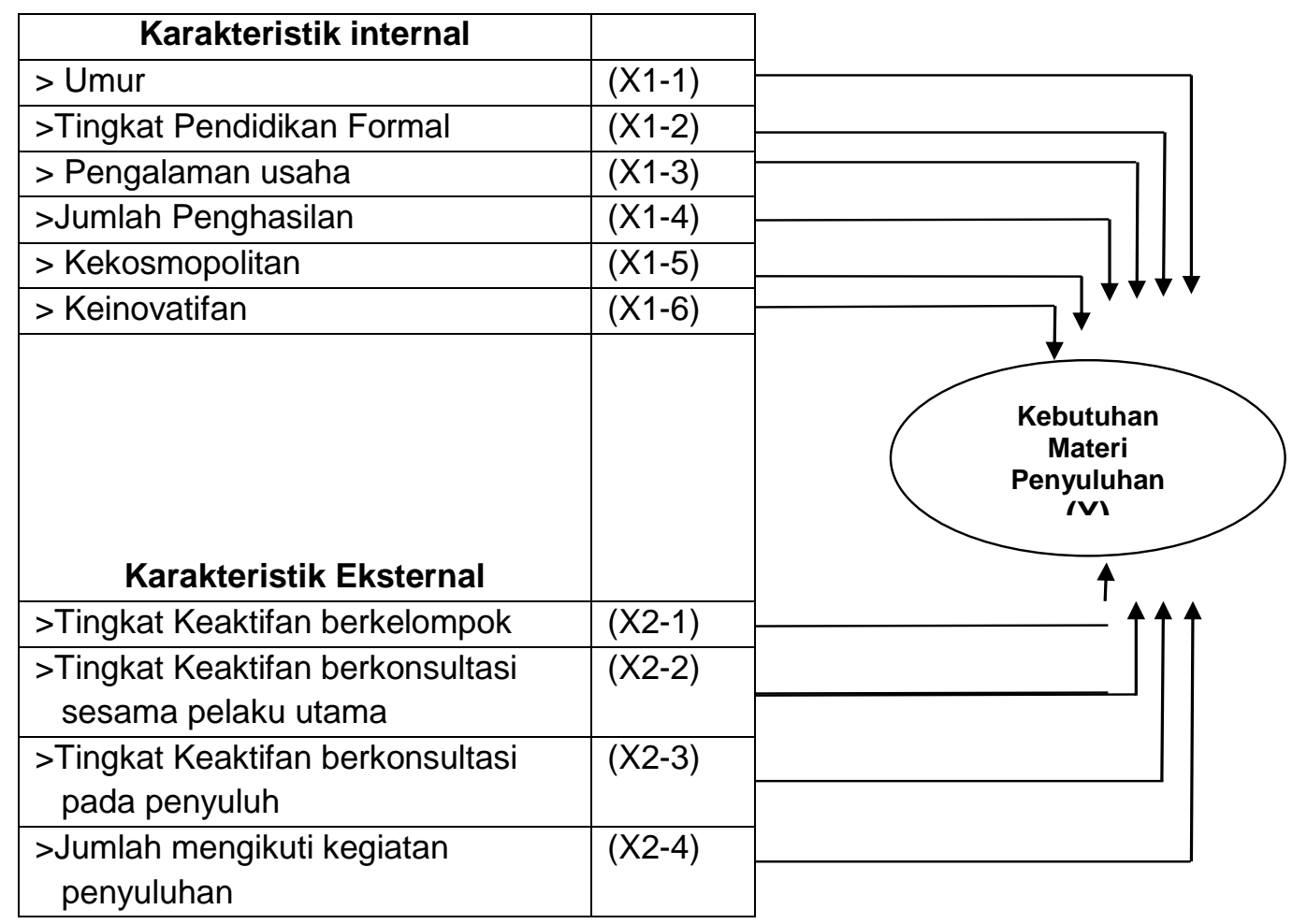

Gambar 1. Kerangka Pikir Hubungan karakteristik Internal dan ekternal dengan kebutuhan materi penyuluhan

\section{Hipotesis Penelitian}

1) Terdapat hubungan yang nyata antara karakteristik internal dengan kebutuhan matari penyuluhan

2) Terdapat hubungan yang nyata antara karakteristik eksternal dengan kebutuhan materi penyuluhan

\section{METODE PENELITIAN}

Penelitian dilakukan di Kabupaten Purbalingga Propinsi Jawa Tengah dengan pertimbangan di kabupaten tersebut terdapat 13257 RTP pembudidaya ikan dan terdapat 25 (dua puluh lima) penyuluh perikanan fungsional. Penelitan dilakukan selama 4 (empat) minggu mulai Bulan April sampai Bulan Mei 201.
Dari populasi pelaku utama perikanan yang berada di Kabupaten Purbalingga yang dijadikan sampel sebanyak 70 orang yang diambil secara acak dari 12 kecamatan. Populasi relatif homogen dalam kegiatan usaha budidaya ikan, sehingga responden yang terambil dapat mewakili populasi tersebut

Data yang dikumpulkan terdiri dari data primer dan data sekunder. Data primer dikumpulkan dengan wawancara kepada pelaku utama pembudidaya ikan menggunakan daftar pertanyaan (kuisioner) yang telah disiapkan, dan dilakukan juga wawancara mendalam (indepth interview) dengan ketua kelompok, Penyuluh Perikanan, dan Kepala Desa. Data sekunder dikumpulkan dari Badan Pelaksana 
Penyuluhan Kabupaten dan Balai Penyuluhan di Kecamatan.

Analisa data dilakukan secara deskriftif, analisa kualitatif dilakukan untuk semua tujuan penelitian, analisa kuantitatif dilakukan untuk menguji hipotesis yang diajukan. Faktor internal dan faktor eksternal serta kebutuhan kegiatan penyuluhan pelaku utama perikanan diukur dengan menggunakan distribusi frekuensi dan nilai tengah. Untuk mengetahui hubungan antar peubah dilakukan analisis hubungan dengan koefisien korelasi Spearman, sebagai uji korelasi bagi data non parametrik

\section{HASIL DAN PEMBAHASAN}

Kabupaten Purbalingga mempunyai luas wilayah $77.764,122$ ha (Tabel 1.), yang terdiri dari luas sawah 21.715,033 ha dan lahan kering 56.049,089 ha.

Tabel 1. Data Potensi Lahan Perikanan

\begin{tabular}{clccc}
\hline NO & KECAMATAN & \multicolumn{3}{c}{ POTENSI LAHAN UNTUK PERIKANAN ( Ha ) } \\
\cline { 3 - 5 } & & POTENSI & KOLAM & BELUM KOLAM \\
\hline $\mathbf{1}$ & \multicolumn{1}{c}{$\mathbf{2}$} & $\mathbf{3}$ & $\mathbf{4}$ & $\mathbf{5}$ \\
\hline 1 & Purbalingga & 52,40 & 30,82 & 21,58 \\
2 & Kalimanah & 40,10 & 14,55 & 25,55 \\
3 & Padamara & 38,20 & 21,50 & 16,70 \\
4 & Kutasari & 45,80 & 22,40 & 23,40 \\
5 & Bojongsari & 45,90 & 25,30 & 20,60 \\
6 & Kemangkon & 60,30 & 29,83 & 30,47 \\
7 & Kaligondang & 22,40 & 7,04 & 15,36 \\
8 & Bobotsari & 36,80 & 15,20 & 21,60 \\
9 & Mrebet & 55,60 & 14,10 & 41,50 \\
10 & Karanganyar & 22,17 & 6,59 & 15,58 \\
11 & Kertanegara & 22,20 & 6,70 & 15,50 \\
12 & Karangreja & 12,13 & 1,56 & 10,57 \\
13 & Karangjambu & 7,60 & 2,32 & 5,28 \\
14 & Bukateja & 83,20 & 41,06 & 42,14 \\
15 & Kejobong & 13,40 & 5,06 & 8,34 \\
16 & Pengadegan & 8,50 & 3,06 & 5,44 \\
17 & Rembang & 12,20 & 3,72 & 8,48 \\
18 & Karangmoncol & 27,10 & 6,57 & 20,53 \\
\hline & Jumlah & $\mathbf{6 0 6 , 0 0}$ & $\mathbf{2 5 7 , 3 8}$ & $\mathbf{3 4 8 , 6 2}$ \\
\hline
\end{tabular}

Pembangunan perikanan di suatu daerah tidak terlepas dari potensi sumberdaya manusia yang dimilikinya. Kabupaten Purbalingga dengan potensi sumberdaya manusianya sangat mendukung upaya peningkatan pembangunan di sektor perikanan. Sumberdaya manusia tersebut meliputi :

a. Rumah Tangga Perikanan (RTP) berjumlah RTP yang terdiri dari :

- RTP Kolam Budidaya : 9.349 RTP - RTP Mina Padi : 860 RTP
- RTP Karamba (Sariban) : - RTP - RTP Nelayan Sungai : 2.731 RTP

b. Kelompok Pembudidaya Ikan (Pokdakan). Dari Rumah Tangga Perikanan tersebut sudah ada yang bergabung dalam kelompok sebanyak 102 Pokdakan. Pembudidaya ikan yang sudah masuk dalam Pokdakan sebanyak 1.922 orang.

Usaha Perikanan yang dilakukan di Kabupaten Purbalingga cukup bervariasi 
sesuai dengan kondisi dan situasi wilayah, diantaranya dengan sistem kolam air tenang, UPR (Unit Pembenihan Rakyat), Mina Padi, Perairan Umum, Pengelolaan hasil perikanan dan beberapa karamba. Untuk lebih jelasnya, jenis usaha dan nilai produksi perikanan dapat dilihat pada Tabel 2.

Tabel 2. Jenis Usaha dan Nilai Produksi Perikanan

\begin{tabular}{|c|c|c|c|c|c|c|c|}
\hline \multirow[b]{2}{*}{ No } & \multirow{2}{*}{$\begin{array}{l}\text { Jenis } \\
\text { Usaha }\end{array}$} & \multicolumn{2}{|c|}{ Luas lahan (ha) } & \multicolumn{2}{|c|}{2009} & \multicolumn{2}{|c|}{2010} \\
\hline & & 2009 & 2010 & Produksi & $\begin{array}{l}\text { Nilai Prod } \\
\text { (Rp.1.000) }\end{array}$ & Produksi & $\begin{array}{l}\text { Nilai Prod } \\
\text { (Rp. 1.000) }\end{array}$ \\
\hline 1 & $\begin{array}{l}\text { Pembenih } \\
\text { an }\end{array}$ & 17,19 & 18,14 & 204.884 .000 & 3.706 .159 & 285.021 .000 & 5.352 .674 \\
\hline 2 & $\begin{array}{l}\text { Pembesar } \\
\text { an }\end{array}$ & 257,38 & 258,60 & 8.134 .950 & 107.796.909 & 9.233 .900 & 130.911 .604 \\
\hline 3 & Mina pada & 215,160 & 215,16 & 64.320 & 1.625 .620 & 72.300 & 1.748 .570 \\
\hline \multirow[t]{3}{*}{4} & $\begin{array}{l}\text { Penangka } \\
\text { pan }\end{array}$ & 420,00 & 420,00 & 257.000 & 3.027 .050 & 250.000 & 2.900 .027 \\
\hline & $\begin{array}{l}\mathrm{Di} \\
\text { perairan }\end{array}$ & & & & & & \\
\hline & Umum & & & & & & \\
\hline \multirow[t]{3}{*}{5} & Karamba & - & - & - & - & - & - \\
\hline & Sungai & & & & & & \\
\hline & & 909,73 & 911,90 & 213.340 .270 & 137.124.286 & 294.577.200 & 140.912 .875 \\
\hline
\end{tabular}

Sumber: Dinas Peternakan dan Perikanan Kabupaten Purbalingga

Karakteristik responden yang diamati dalam penelitian ini meliputi faktor internal (umur, lama pendidikan, pengalaman usaha, kekosmopolitan, dan keinovatifan). Sebaran karakteristik internal responden seperti pada Tabel 3.

Tabel 3. Sebaran karakteristik Internal Responden

\begin{tabular}{|c|c|c|c|c|}
\hline No & $\begin{array}{l}\text { Karakteristik } \\
\text { Internal } \\
\text { Responden }\end{array}$ & Kategori & $\begin{array}{c}\text { Persentase } \\
\quad(n=85)\end{array}$ & Interval \\
\hline \multirow[t]{3}{*}{1} & Umur & Muda $(<35,4$ thn & 16,5 & \\
\hline & & Sedang (35,4-56,4 thn) & 65,9 & $20-63$ \\
\hline & & Tinggi (> 56,4 thn) & 17,6 & thn \\
\hline \multirow[t]{3}{*}{2} & Lama Pendidikan & Rendah ( $<8,3$ thn) & 11,8 & \\
\hline & & Sedang $(8,3-14,1$ thn $)$ & 71,8 & $4-17$ thn \\
\hline & & Tinggi ( > 14,1 th) & 16,4 & \\
\hline \multirow[t]{3}{*}{3} & Pengalaman Usaha & Rendah ( < 1,3 thn) & 7,1 & \\
\hline & & Sedang $(1,3-16,1$ thn $)$ & 82,4 & $1-37$ th \\
\hline & & Tinggi ( > 16,1 th) & 10,5 & \\
\hline \multirow[t]{3}{*}{4} & Tingkat & Rendah $(<1,4)$ & 10,5 & \\
\hline & Kekosmopolitan & Sedang $(1,4-2,4)$ & 83,5 & $1-3$ \\
\hline & & Tinggi ( > 2,4) & 6,0 & \\
\hline \multirow[t]{3}{*}{5} & Tingkat Keinovatifan & Rendah $(<1,6)$ & 10,5 & \\
\hline & & Sedang $(1,6-2,6)$ & 72,9 & $1-3$ \\
\hline & & Tinggi $(>2,6)$ & 16,6 & \\
\hline
\end{tabular}


Hasil penelitian menunjukkan bawa umur responden beragam antara 20 - 63 tahun dengan umur rata-rata 45,9 tahun. Responden didominasi oleh umur sedang ( 35,4 - 56,4 tahun). Data umur tersebut menunjukkan bahwa responden sebagai pembudidaya ikan di Kabupaten Purbalingga masih tergolong usia produktif. Umur responden dengan katogiri usia tua ( $>$ 56,4 tahun) hanya $17,6 \%$. Hal ini menunjukkan usaha budidaya ikan banyak diminati kaum muda.

Pendidikan Responden ditinjau dari lamanya mengikuti pendidikan formal mulai dari $4-17$ tahun, artinya ada responden tidak tamat pendidikan sekolah dasar ada pula sebanyak $16,4 \%$ tamat perguruan tinggi. Sebanyak $71,8 \%$ responden tingkat pendidikan sedang (8,3 - 14,1 tahun), dengan demikian responden termasuk yang bisa baca tulis.

Pengalaman responden dalam
melakukan usaha budidaya ikan di
Kabupaten Purbalingga sebanyak $82,4 \%$
tergolong pengalaman yang cukup (antara
$1,3-16,1$ tahun) dan sebanyak $10,5 \%$
termasuk pengalaman yang tinggi.
Berdasarkan data tersebut menunjukkan
bahwa usaha budidaya ikan termasuk usaha
yang konsisten dilakukan responden, karena
merupakan usaha yang menguntungkan dan
didukung oleh faktor kemudahan informasi
dalam pemasaran dan penyediaan sarana
produksi perikanan.

Tingkat kekosmopolitan adalah aktivitas seseorang ke luar lokasi atau daerahnya dalam mencari inovasi-inovasi terkait dengan teknologi budidaya ikan. Pembudidaya ikan di Kabupaten Purbalingga termasuk pembudidaya ikan dengan tingkat kekosmopolitan yang cukup $(83,5 \%)$ hal tersebut menunjukkan bahwa para pembudidaya ikan di kabupaten Purbalingga sangat responsip pada inovasi, sehingga tidak saja menunggu informasi dari para penyuluh perikanan dalam mendapatkan informasi, akan tetapi aktif pula mencari informasi yang dibutuhkan ke luar daerahnya.

Tingkat keinovatifan adalah sikap para pembudidaya ikan untuk mau dan menerapkan inovasi yang diperolehnya pada kegiatan usaha. Hasil penelitian menunjukkan bahwa sekitar $72,9 \%$ para pembudidaya ikan termasuk tingkat keinovatifannya cukup dan sebanyak $16,6 \%$ termasuk tingkat keinovatifannya tinggi. Hal tersebut yang mendukung perkembangan usaha budidaya ikan di Kabupaten Purbalingga, sehingga baik Dinas Perikanan maupun kelembagaan penyuluhan yang ada memudahkan mendifusikan inovasi teknologi perikanan kepada masyarakat.

Karakteristik responden yang diamati dalam penelitian ini meliputi faktor internal (tingkat keatifan berkelompok, ingkat keaktifan berkonsultasi pada sesama pelaku utama, tingkat keaktifan konsultasi kepada penyuluh dan frekuensi mengikuti kegiatan penyuluhan). Sebaran karakteristik ekternal responden seperti pada Tabel 4. 
Tabel 4. Sebaran karakteristik Ekternal Responden

\begin{tabular}{|c|c|c|c|c|}
\hline NO & $\begin{array}{c}\text { Karakteristik Ekternal } \\
\text { Responden }\end{array}$ & Katagori & $\begin{array}{c}\text { Persentase } \\
(n=85)\end{array}$ & Interval \\
\hline \multirow[t]{3}{*}{1} & Tingkat Keaktifan berkelompok & Kurang $(<1,5)$ & 11,8 & \\
\hline & & Cukup $(1,5-2,5)$ & 70,6 & $1-3$ \\
\hline & & Tinggi (> 2,5 ) & 17,6 & \\
\hline \multirow[t]{3}{*}{2} & Tingkat Keaktifan Konsultasi pada Sesama & Kurang $(<1,6)$ & 12,9 & \\
\hline & Pelaku Utama & Cukup $(1,6-2,4)$ & 70,6 & $1-3$ \\
\hline & & Tinggi $(>2,4)$ & 16,5 & \\
\hline \multirow[t]{3}{*}{3} & Tingkat Keaktifan Konsultasi kepada & Kurang $(<1,5)$ & 5,9 & \\
\hline & penyuluh & Cukup $(1,5-2,5)$ & 83,5 & $1-3$ \\
\hline & & Tinggi (> 2,5 ) & 10,6 & \\
\hline \multirow[t]{3}{*}{4} & Frekwensi Mengikuti Kegiatan Penyuluhan & Kurang $(<1,5)$ & 36,5 & \\
\hline & & Cukup $(1,5-2,5)$ & 54,1 & $1-3$ \\
\hline & & Tinggi $(>2,5)$ & 9,4 & \\
\hline \multirow[t]{3}{*}{5} & Tingkat Kebutuhan Materi Penyuluhan & Kurang $(<1,6)$ & 10,6 & \\
\hline & & Cukup $(1,6-2,6)$ & 82,4 & $1-3$ \\
\hline & & Tinggi $(>2,6)$ & 7,0 & \\
\hline
\end{tabular}

Tingkat keaktifan berkelompok adalah aktivitas para responden sebagai anggota suatu kelompok dalam hal mengikuti kegiatan; memberikan saran dan pendapat bagi kemajuan kelompok; iuran anggota; pemanfaatan kelompok dalam pengadaan saprokan dan proses penjualan hasil, mentaati norma dan aturan kelompok. Hasil analisis menunjukkan bahwa pelaku utama perikanan di Kabupaten Purbalingga 70,6\% termasuk katagori aktif dalam berkelompok, dan hanya $11,8 \%$ yang kurang aktif berkelompok. Keaktifan berkelompok para pelaku utama di Kabupaten purbalingga didukung oleh keberadaan kelompok pada setiap kawasan budidaya ikan dan keatifan para penyuluh perikanan dalam membina kelompok-kelompok yang ada.

Para pelaku utama di Kabupaten Purbalingga termasuk yang sering bertukar informasi terhadap sesama. Hasil penelitian menunjukkan $83,5 \%$ para pembudiddaya termasuk katagori yang aktif saling tukar informasi dengan sesama dan hanya 5,9\% yang dikatagorikan kurang aktif

Peran penyuluh sebagai tempat konsultasi para pelaku utama di Kabupaten Purbalingga $36,5 \%$ termasuk yang kurang aktif berkonsultasi kepada para penyuluh, dan hanya sekitar $54,1 \%$ yang sering berkonsultasi, dan hanya $9,4 \%$ yang termasuk katagori sangat aktif berkonsultasi kepada para penyuluh. Namun secara keseluruhan termasuk katagori cukup.

Hasil penelitian memperlihatkan bahwa $82,4 \%$ pelaku utama perikanan termasuk yang aktif mengikuti kegiatan penyuluhan perikanan, dan hanya sekitar $10,6 \%$ yang katagorinya kurang aktif. Hal ini menunjukkan bahwa para pelaku utama perikanan sangat tinggi kebutuhannya akan informasi inovasi teknologi perikanan.

Hasil penelitian menunjukkan sebanyak $82,4 \%$ pembudidaya ikan di Kabupaten Purbalingga sangat membutuhkan informasi materi penyuluhan baik pada aspek teknis, sosial maupun ekonomi. Dan hanya 10,6\% katagori dari pelaku utama yang kurang membutuhkan materi penyuluhan. Banyaknya pembudidaya ikan yang membutuhkan informasi materi penyuluhan perikanan mengindikasikan bahwa usaha perikanan cukup diminati dan merupakan bidang pekerjaan yang cukup menjanjikan.

Hasil analisis hubungan antara faktor pribadi, faktor internal dan faktor ekternal pembudidaya ikan ikan, disajikan pada Tabel 5. 
Tabel 5. Sebaran Persentase faktor Pribadi Pembudidaya Ikan

\begin{tabular}{|c|c|c|c|c|c|}
\hline \multicolumn{2}{|c|}{ Karakteristik } & \multicolumn{3}{|c|}{ Lama Pendidikan } & \multirow[b]{2}{*}{ Jumlah } \\
\hline \multicolumn{2}{|c|}{ Karakteristik } & $\begin{array}{l}\text { Rendah } \\
\text { ( }<8,3 \text { th) }\end{array}$ & $\begin{array}{c}\text { Sedang } \\
(8,3-14,1 \\
\text { th) }\end{array}$ & $\begin{array}{c}\text { Tinggi } \\
\text { (> 14,1 } \\
\text { th) }\end{array}$ & \\
\hline \multirow{3}{*}{ Umur } & Muda ( $<35,4$ th) & 7,1 & 64,3 & 28,6 & 100 \\
\hline & Sedang $(35,4-56,4$ th) & 8,9 & 78,6 & 12,5 & 100 \\
\hline & Tua ( $>56,4$ th) & 26,7 & 66,7 & 16,6 & 100 \\
\hline
\end{tabular}

Pada Tabel 6, memperlihatkan bahwa pembudidaya ikan di Kabupaten Purbalingga yang hanya tamat SD (pendidikan kurang 8,3 th) sebanyak 7,1\% dan sebanyak $64,3 \%$ pembudidaya ikan tamat pendidikan SD sampai setara D1 dan sebanyak $28,6 \%$ termasuk yang kategori sarjana. Secara umum ada kecenderungan semakin tua umur responden persentase tingkat pendidikan semakin rendah, dan sebaliknya semakin muda umur pembudidaya ikan semakin tinggi tingkat pendidikan.

Tabel 6. Sebaran Persentase faktor Pribadi Pembudidaya Ikan

\begin{tabular}{|c|c|c|c|c|c|}
\hline \multicolumn{2}{|c|}{ Karakteristik } & \multicolumn{3}{|c|}{ Pengalaman Usaha } & \multirow[b]{2}{*}{ Jumlah } \\
\hline Karakt & ristik & $\begin{array}{c}\text { Rendah } \\
(<1,3 \\
\text { th })\end{array}$ & $\begin{array}{c}\text { Sedang } \\
(1,3-16,1 \text { th })\end{array}$ & $\begin{array}{c}\text { Tinggi } \\
(>16,1 \mathrm{th})\end{array}$ & \\
\hline \multirow{3}{*}{ Umur } & Muda ( $<35,4$ th) & 20 & 80 & 0 & 100 \\
\hline & Sedang $(35,4-56,4$ th $)$ & 3,8 & 84,9 & 11,3 & 100 \\
\hline & Tua ( $>56,4$ th) & 20 & 73,3 & 6,7 & 100 \\
\hline
\end{tabular}

Tabel 6, menunjukkan bahwa sebanyak $80 \%$ pembudidaya muda umumnya pengalaman usahanya sedang, dan tidak ada yang punya pengalaman tinggi. Sedangkan $11,3 \%$ pengalaman yang tinggi pada pembudidaya dengan katagori usia yang sedang $(35,4$ - 56,7 tahun). Demikian juga pada usia yang tua (lebih 56,7 tahun) tidak menunjukkan pengamanan usaha yang tinggi (hanya $6,7 \%$ ), sebanyak $73,3 \%$ para pembudidaya ikan pada kategori pengalaman yang cukup.

Tabel 7. Sebaran Persentase umur dengan faktor internal

\begin{tabular}{llcccc}
\hline Karakteristik & \multicolumn{3}{c}{ Kekosmopolitan } & \multirow{2}{*}{ Jumlah } \\
\cline { 2 - 5 } Karakteristik & $\begin{array}{c}\text { Rendah } \\
(<\mathbf{1 , 4})\end{array}$ & $\begin{array}{c}\text { Sedang } \\
(\mathbf{1}, \mathbf{4}-\mathbf{2 , 4})\end{array}$ & $\begin{array}{c}\text { Tinggi } \\
(>\mathbf{2 , 4})\end{array}$ & \\
\hline \multirow{3}{*}{ Umur } & Muda $(<35,4$ th) & 33,3 & 22,2 & 44,5 & 100 \\
& Sedang(35,4-56,4 th $)$ & 2,8 & 90,1 & 7,1 & 100 \\
& Tua $(>56,4$ th) & 60 & 0 & 40 & 100 \\
\hline
\end{tabular}


Tabel 8. Sebaran Persentase umur dengan faktor internal

\begin{tabular}{|c|c|c|c|c|c|}
\hline \multirow{2}{*}{\multicolumn{2}{|c|}{ Karakteristik }} & \multicolumn{3}{|c|}{ Keinovatifan } & \multirow[b]{2}{*}{ Jumlah } \\
\hline & & $\begin{array}{c}\text { Rendah } \\
(<1,6)\end{array}$ & $\begin{array}{c}\text { Sedang } \\
(1,6-2,6)\end{array}$ & $\begin{array}{l}\text { Tinggi } \\
(>2,6)\end{array}$ & \\
\hline \multirow[t]{3}{*}{ Umur } & Muda ( $<35,4$ th) & 22,2 & 22,2 & 55,6 & 100 \\
\hline & Sedang $(35,4-56,4$ th $)$ & 5,6 & 80,2 & 4,2 & 100 \\
\hline & Tua ( $>56,4$ th) & 60 & 40 & 0 & 100 \\
\hline
\end{tabular}

\section{Nilai Korelasi Antara Karakteristik Pembudidaya Ikan}

Nilai korelasi pada karateristik internal para pembudidaya ikan di kabupaten Purbalingga disajikan pada Tabel 9.

Tabel 9. Nilai Korelasi Antara Faktor Internal Pembudidaya Ikan

\begin{tabular}{lccc}
\hline Karakteristik Internal & Kekosmopolitan & Keinovatifan & $\begin{array}{c}\text { Keaktifan } \\
\text { Berkelompok }\end{array}$ \\
\hline Umur & $-0,141$ & $-\mathbf{0 , 2 1 1 ^ { * }}$ & $-0,027$ \\
Pendidikan formal & 0,011 & 0,150 & $-0,014$ \\
Pengalaman usaha & 0,001 & 0,007 & $\mathbf{0 , 2 1 9 *}$ \\
\hline
\end{tabular}

Keterangan: * Hubungan yang erat pada taraf kepercayaan 0,05

${ }^{* *}$ Hubungan yang sangat erat pada taraf kepercayaan 0,01

Pada Tabel 9, menunjukkan bahwa hasil analisis umur para pembudidaya ikan di Kabupaten Purbalingga mempunyai hubungan yang erat dengan tingkat keinovatidfan (nilai korelasi 0,211*). Pendidikan formal para pembudidaya ikan tidak berhubungan erat baik pada tingkat kekosmopolitan, tingkat keinovatifan maupun tingkat keaktifan berkelompok. Sedangkan pengalaman usaha para pembudidaya ikan di Kabupaten Purbalingga memiliki hubungan yang erat
(Nilai Korelasi $0,219^{\star}$ ) dengan tingkat keaktifan berkelompok.

\section{Korelasi Antara Karakteristik Internal dengan Karakteristik Ekternal}

Hasil analisis Korelasi Rank Spearman antara karakteristik pelaku utama perikanan dengan tingkat kebutuhan materi penyuluhan perikanan di Kabupaten Purbalingga disajikan pada Tabel 10.

\section{Tabel 10. Nilai Korelasi Karakteristik Pelaku Utama dengan Tingkat Kebutuhan Materi Penyuluhan}

\begin{tabular}{|c|c|c|c|}
\hline $\begin{array}{l}\text { Tk Kebutuhan } \\
\text { Karakteristik }\end{array}$ & $\begin{array}{c}\text { Konsul tasi pada } \\
\text { sesama }\end{array}$ & $\begin{array}{c}\text { Konsultasi pada } \\
\text { penyuluh }\end{array}$ & Mengikuti penyuluhan \\
\hline Umur & 0,011 & $(-0,084)$ & 0,079 \\
\hline Pendidikan formal & $(-0,009)$ & 0,114 & 0,048 \\
\hline Pengalaman usaha & $(-0,014)$ & 0,04 & $0,209^{*}$ \\
\hline Kekosmopolitan & $0,548^{\star \star}$ & $0,367^{\star \star}$ & 0,139 \\
\hline Keinovatifan & $0,664^{\star \star}$ & $0,496^{\star *}$ & $0,564^{\star \star}$ \\
\hline Keaktifan berkelompok & $0,369^{\star \star}$ & $0,340^{\star *}$ & $0,381^{\star *}$ \\
\hline
\end{tabular}

Keterangan: * Hubungan yang erat pada taraf kepercayaan 0,05

${ }^{* \star}$ Hubungan yang sangat erat pada taraf kepercayaan 0,01 
Hasil analisis menunjukkan bahwa umur dan pendidikan para pembudidaya ikan di Kabupaten Purbalingga tidak menunjukkan korelasi (hubungan) yang erat dengan tingkat kebutuhan materi penyuluhan baik yang diperoleh dari sesama pembudidaya ikan, dari penyuluh perikanan, maupun seringnya mengikuti kegiatan penyuluhan. Sedangkan pengalaman usaha menunjukkan punya hubungan yang erat dengan kebutuhan materi penyuluhan perikanan (nilai korelasi $0, \mathbf{2 0 9}^{\star}$ ) yaitu dengan seringnya mengiktui kegiatan penyuluhan perikanan.

Tingkat kekosmpolitan pembudidaya ikan di Kabupaten Purbalingga berhubungan sangat erat dengan kebutuhan materi penyuluhan yang ditandai dengan para pembudidaya ikan tersebut seringnya berkonsultasi kepada sesama pembudidaya ikan (Nilai korelasi $\mathbf{0 , 2 5 9 ^ { \star \star }}$ ) dan penyuluh

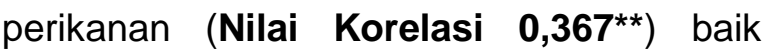
materi teknis, sosial maupun materi ekonomi. Namun demikian tingkat kekosmopolitan para pembudidaya ikan tersebut tidak berkorelasi yang erat dengan frekuensi mengikuti kegiatan penyuluhan.

Tingkat keinovatifan dan keaktifan para pembudidaya ikan di Kabupaten Purbalingga menunjuukkan hubungan yang sangat erat dengan tingkat kebutuhan materi penyuluhan. Hal tersebut diketahui dengan seringnya berkonsultasi terhadap sesama pembudidaya ikan terkait usaha yang dilakukannya (Nilai Korelasi 0,664**), seringnya berkonsultasi kepada penyuluh

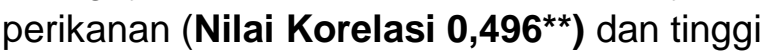
keaktifan mengikuti kegiatan penyuluhan perikanan (Nilai Korelasi 0,190*).

Tingkat keaktifan berkelompok para pembuddaya ikan dan menjalankan fungsifungsi yang ada dikelompok berkaitan sangat erat para pembudidaya ikan tersebut dengan kebutuhan pada materi penyuluhan perikanan untuk mengembangkan usahanya. Hasil analisis menunjukkan para pembudidaya ikan memperoleh nilai korelasi $\mathbf{0 , 3 6 9 ^ { * * }}$ pada kegiatan mencarai informasi materi usaha perikanan kepada sesama pembudidaya ikan, memperoleh nilai korelasi $0,340^{\star *}$ mencari materi usaha perikanan kepada penyuluh perikanan, dan memperoleh nilai korelasi $\mathbf{0 , 3 8 1 ^ { \star \star }}$ mencari materi usaha perikanan dengan keaktifan berkelompok.

\section{KESIMPULAN DAN SARAN}

\section{Kesimpulan}

1) Pelaku utama perikanan di Kabupaten Purbalingga tingkat keaktifan berkelompok, tingkat keaktifan berkonsultasi pada sesama, tingkat keaktifan berkonsultasi pada penyuluh, frekuensi mengikuti kegiatan penyuluhan dan tingkat kebutuhan pada materi penyuluhan pada kategori cukup baik.

2) Pelaku utama pada umur sedang $(35,4$ - 56,4 tahun) umumnya 78,6 \% lama pendidikan sedang (8-14 tahun), 84,9 $\%$ pengalaman usaha sedang, 90,1\% tingkat kekosmopolitan sedang, 80,2 $\%$ tingkat keinovatifan sedang.

3) Umur pelaku utama berkorelasi erat dengan tingkat keinovatifan, sedangkan pengalaman usaha berkorelasi erat dengan keaktifan berkelompok.

4) Kekosmopolitan, keinovatifan dan keaktifan berkelompok berkorelasi sangat erat dengan tingkat konsultasi pada sesama dan pada penyuluh dan mengikuti penyuluhan.

\section{Saran}

1) Dalam penentuan materi penyuluhan perikanan harus dipertimbangkan karakteristik sasaran penyuluhan (umur, pendidikan, kekosmopolitan dan keinovatifan) 
2) Dalam menyusun kebutuhan materi penyuluhan perlu perlibatan pelaku utama secara partisipatif

3) Perlu dilakukan penelitian di Kabupaten lain dengan keberadaan penyuluh perikanan yang kurang atau tidak ada penyuluh perikanan.

\section{DAFTAR PUSTAKA}

Anonimous, Undang-Undang No. 16 tahun 2006. Sistem Penyuluhan Pertanian, Perikanan dan Kehutanan

Alimin, 2004. Faktor Yang berhubungan dengan kebutuhan latihan Petani Sayur-sayuran (Kasus di Kecamatan Sukanagara Kab. Cianjur) Makalah tesis Program Studi PPN IPB.

Donaldson, L \& EE Scanel, 1992. Human Resource Development: te New
Trainer's Guide. San Juan: AddisonWesley Publishing Co. Inc.

Laksana, F. 2008. Manajemen Pemasaran (Pendekatan Praktis). Graha IImu. Yogjakarta.

Lionberger, H.F., \& P.H. Gwin, 1982. Communication Strategies : a Guide for Agricultural Change Agents, Danville, Illiois: The Interstate Printers \& Publishers, Inc.

Nuraeni, I. 2002. Diktat Manajemen Agribisnis. STP Bogor

Rahardi, F. 2008. Agribisnis Perikanan. Penebar Swadaya. Jakarta.

Rogers, E.M. \& FF Shoemaker, 1987. Memasyarakatkan Ide-lde baru. Disarikan oleh Abdillah hanafi. Surabaya: Usaha Nasional. 